\title{
Seasonal Variations in the Bacterial Community of Gwangyang Bay Seawater
}

\author{
Seong Chan Park' ${ }^{1}$, Ji Hee Lee ${ }^{2}$, Joo Won Kang ${ }^{2}$, Keun Sik Baik ${ }^{3}$ and Chi Nam Seong ${ }^{2 *}$ \\ ${ }^{1}$ Woogene B\&G Rearch Institute, Seoul 150-972, Korea \\ ${ }^{2}$ Department of Biology, Sunchon National University, Suncheon 540-950, Korea \\ ${ }^{3}$ Division of Life Sciences, Korea Basic Science Institute, Daejean 305-806, Korea
}

Received February 26, 2014 /Revised May 3, 2014 /Accepted May 21, 2014

\begin{abstract}
Seasonal variations in the bacterial community of Gwangyang Bay seawater were analyzed using both isolation and cultivation-independent methods. Amplified rDNA restriction analysis was applied to 200 bacterial isolates. Bacterial isolates were composed of four phyla: Firmicutes, Proteobacteria, Actinobacteria, and Bacteroidetes. Pyrosequencing was conducted, in addition to denaturing gradient gel electrophoresis (DGGE) of genomic DNA extracted directly from the water samples. The bacterial sequences obtained by pyrosequencing of $16 \mathrm{~S}$ rRNA genes consisted of 24 phyla in the spring and summer, 39 in the fall, and 32 in the winter. The diversity index was high in the fall, whereas the dominancy index was high in the spring. In the spring, phylum Firmicutes was dominant, whereas phylum Proteobacteria dominated in the other three seasons. The second most dominant phyla were Proteobacteria in the spring, Firmicutes in the summer, and Bacteroidetes both in the fall and winter. Bacilliaceae was the most predominant family in the spring. Rhodobacteraceae and Bacilliaceae dominated in the summer, and Rhodobacteraceae dominated in the winter. Neither was dominant in the fall Twenty-seven bands purified from DGGE profiles were cloned and analyzed phylogenetically. In the spring, phylum Firmicutes dominated, followed by Proteobacteria. Proteobacteria dominated in all other seasons. Thus, two cultivation-independent methods for determination of seasonal variation patterns at the phylum level were in accordance with each other.
\end{abstract}

Key words : Amplified rDNA restriction analysis, bacterial community, denaturing gradient gel electrophoresis, pyrosequencing

\section{Introduction}

Gwangyang bay is located in the southern coastal region surrounded by Yeosu Peninsula and Namhae Island, Republic of Korea $\left(34^{\circ} 51^{\prime} 16^{\prime \prime} \sim 34^{\circ} 56^{\prime} 55^{\prime \prime} \mathrm{N}, 127^{\circ} 37^{\prime}\right.$ $23^{\prime \prime} \sim 127^{\circ} 50^{\prime} 86^{\prime \prime}$ E). Gwangyang bay, which receives freshwater via Seomjin River, is semi-closed and linked to the South Sea via two channels, Yeosu and Noryang, to the south and the east, respectively. The surface area of the bay is $230 \mathrm{~km}^{2}$ and contains 20 islets. A large-scale steel works, container port, and heavy-chemical estate were constructed in the coastal region of the bay. In recent years, this area has been designated as a special management area for coastal pollution, receiving great attention from the public due to its increasing environmental problems. There have been

\footnotetext{
*Corresponding author

Tel : +82-61-750-3613, Fax : +82-61-750-5469

E-mail : scnu@sunchon.ac.kr

This is an Open-Access article distributed under the terms of the Creative Commons Attribution Non-Commercial License (http://creativecommons.org/licenses/by-nc/3.0) which permits unrestricted non-commercial use, distribution, and reproduction in any medium, provided the original work is properly cited
}

several investigations into the functions of environmental factors, water quality, and planktons and benthos $[2,6,22]$, whereas studies on microorganisms are few. Therefore, we carried out systematic cataloguing of the microbial community of Gwangyang bay seawater.

The objective of this study was to examine seasonal variations in the bacterial community of Gwangyang bay seawater. To achieve this goal, cultivation - dependent and - independent analyses, such as pyrosequencing and denaturing gradient gel electrophoresis (DGGE) followed by phylogenetic analysis, were performed.

\section{Materials and Methods}

\section{Sampling and environmental factors}

Seawater samples were taken four times (April, July, October 2008, and February 2009) at a surface depth of 1 $\mathrm{m}$ in the mouth of Yeosu channel in Gwangyang bay,

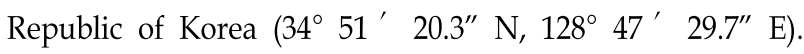
Samplings were carried out at ebb tide. Temperature, $\mathrm{pH}$, salinity, dissolved oxygen, heterotrophic bacterial number, and chlorophyll a content of the samples were checked ac- 
cording to Standard Methods [1].

\section{Isolation of bacteria}

Isolation of bacteria was achieved by the standard dilution plating technique using marine agar 2216 (MA, Becton Dickinson) at $25^{\circ} \mathrm{C}$ for 7 days. Purified isolates were routinely cultured on MA and maintained as a glycerol suspension $(20 \%, \mathrm{w} / \mathrm{v})$ at $-80^{\circ} \mathrm{C}$.

\section{Amplified rDNA restriction analysis (ARDRA) of isolates}

Bacterial DNA preparation and PCR amplification were carried out as previously described [7]. Universal primers such as 27F ( $E$. coli numbering 8 27; $5^{\prime}$-AGA GTT TGA TCM TGG CTC AG-3') and 1492R (E. coli numbering 1492 1510; 5'-GGY TAC CTT GTT ACG ACT T-3') were used for amplification of the 16S rRNA gene [21]. PCR amplification of the nearly full-length $16 \mathrm{~S}$ rRNA gene was performed in $50 \mu \mathrm{l}$ reaction mixtures. PCR products were detected after $1 \%$ agarose gel electrophoresis.

Amplified 16S rRNA genes were digested with HadII (GG $\downarrow$ CC; TaKaRa) as previously described [3]. The resulting fragments were electrophoresed on a 4\% NuSieve 3:1 Agarose (Cambrex, USA) gel, followed by EtBr staining and photography by UV transillumination. Similarities were estimated using the Gelcompar II program 4.6 software (Applied Maths).

$16 \mathrm{~S}$ rRNA genes obtained from representative clones of all phylotypes were partially sequenced using automated DNA sequencer (ABI3700, Applied Biosystems) with the sequencing primer 27F [21]. DNA sequences were edited using PHYDIT. All sequences were analyzed for the presence of chimera using the CHIMERA CHECK program (http:// decipher.cee.wisc.edu/[35]). Partial 16S rRNA gene sequences were identified using EzTaxon-e database (http:// eztaxon-e.ezbiocloud.net/[19]).

\section{DNA extraction from water sample}

Total microbial DNA was directly extracted from the seawater samples. Suspended solids of water samples were removed with filter paper (Whatman no. 2), followed by concentration using a filter unit $(0.22 \mu \mathrm{m})$ (Sterivex-GP, Millipore). DNA extraction was achieved by following previously described method [34]. The quality and concentration of DNA were examined by standard electrophoresis, and spectrophometry using UV/vis spectropho- tometer (Ultraspec2100 pro, GE Healthcare Life Sciences). DNA concentration was adjusted to $300 \mathrm{ng} / \mathrm{\mu l}$ for the next studies.

\section{Pyrosequencing}

The four genomic DNA samples were diluted to $1: 5$ and 1:100. These eight diluted genomic DNA samples were then amplified separately using the bacterial primer pair 27F (E. coli numbering $8 \sim 27 ; 5^{\prime}-x x x$ ACGAG TTT GAT CMT GGC TCA G-3 ') and 518R (E. coli numbering 518 534; 5'-xxxAC WTT ACC GCG GCT GCT GG-3') [9], generating the PCR V3 region of the $16 \mathrm{~S}$ rRNA fragments of c. $400 \mathrm{bp}$, where $x x x$ was designed for the sample identification barcoding key and $A C$ represents linker. Each $50 \mu \mathrm{l}$ PCR reaction included the following: dNTP (2.5 mM), $5 \mu \mathrm{l}$; Ex Taq DNA polymerase $(5 \mathrm{U}), 0.25 \mu \mathrm{l}$; template DNA (100 ng/ $/ \mathrm{l}), 1 \mu \mathrm{l}$; BSA $(4 \mu \mathrm{g} / \mu \mathrm{l}), 5 \mu \mathrm{l}$; reaction buffer [10 mM Tris- $\mathrm{HCl}, 40 \mathrm{mM}$ $\mathrm{KCl}, 2.5 \mathrm{mM} \mathrm{MgCl}$ ], $5 \mu \mathrm{l}$; and each primer $(20 \mu \mathrm{M}), 1 \mu \mathrm{l}$. PCR was conducted on a thermal cycler (TP600, TaKaRa) under the following conditions: $94^{\circ} \mathrm{C}$ for $5 \mathrm{~min} ; 30$ cycles consisting of $94^{\circ} \mathrm{C}$ for $30 \mathrm{~s}, 50^{\circ} \mathrm{C}$ for $30 \mathrm{~s}$, and $72^{\circ} \mathrm{C}$ for 40 s; and a final extension at $72^{\circ} \mathrm{C}$ for $10 \mathrm{~min}$. PCR products were detected after $1 \%$ agarose gel electrophoresis, purified using the gel extraction kit (QIAquick, QIAGEN), and pooled to obtain eight amplicon libraries. Amplicon length and concentration were estimated, and an equimolar mix of all eight amplicon libraries was used for pyrosequencing. Pyrosequencing of the eight amplicon libraries on the Roche 454 GS FLX Titanium system at Macrogen (Korea) resulted in 150,264 reads satisfying the sequence quality criteria employed [11].

\section{Pyrosequencing data analysis}

Initially, the raw sequences obtained from pyrosequencing were processed using an adequate software (GL FLX, Roche) for sorting according to the key (i.e., sequences from the suspended and attached samples), with low quality sequences discarded, and the primer sequences trimmed. In addition, sequences less than $300 \mathrm{bp}$ long were discarded. The processed sequences were subjected to taxonomical classification using the EzTaxon-e database (http://eztaxon-e.ezbiocloud.net/[19]). Clustering of tags into operational taxonomic units (OTUs) and generation of rarefaction curves were carried out using the pyrosequencing pipeline of the Ribosomal RNA database project (http://pyro.cme.msu.edu/ [10]). Classification criteria based on sim- 
ilarity for the species, genus, family, order, class, and phylum are $\geq 97 \%, \geq 94 \%, \geq 90 \%, 85 \%, \geq 80 \%$, and $\geq 75 \%$, respectively. The program DOTUR [32] was employed to calculate diversity estimates, namely the abundance-based coverage estimator ACE [5] and species diversity estimator Chao1 [4], by using sampling without replacement. Rarefaction curves were calculated by using the analytical approximation algorithm described by Hurlbert [16], and 95\% confidence intervals were estimated as described by Heck et al. [14]. Assignment of a sequence to the same group (phylotype) was determined with similarities $\geq 97 \%$.

\section{Denaturing gradient gel electrophoresis}

Amplification of partial 16S rRNA genes for DGGE was performed the same as in pyrosequencing, except that $803 \mathrm{R}$ (E. coli numbering 803 826; 5'-GAA AAA TCC CCG CAG CAA CCA TAG-3') was used as reverse primer. Purified DNAs were amplified again for the V3 region of $16 \mathrm{~S}$ rRNA genes. Primer pairs used were 341F-GC ( 5 ' -CGC CCG CCG CGC GCG GCG GGC GGG GCG GGG GCA CGG GGG GCC TAC GGG AGG CAG CAG-3' ) and 518R (5' -WTT ACC GCG GCT GCT GG-3 ' ). Preparation of the reaction mixture was the same as above, except for the primers. PCR conditions were as follows: initial denaturation at $94^{\circ} \mathrm{C}$ for $5 \mathrm{~min}$, followed by 20 cycles of $30 \mathrm{~s}$ at $94^{\circ} \mathrm{C}$, annealing at $65-55^{\circ} \mathrm{C}$ (in the first cycle, annealing was conducted at $65^{\circ} \mathrm{C}$, after which the temperature was reduced by $0.5^{\circ} \mathrm{C}$ in each following cycle) for $30 \mathrm{~s}$, and extension at $72^{\circ} \mathrm{C}$ for $30 \mathrm{~s}$. This procedure was followed by 10 cycles of $30 \mathrm{~s}$ at $94^{\circ} \mathrm{C}$, $30 \mathrm{~s}$ at $55^{\circ} \mathrm{C}$, and $30 \mathrm{~s}$ at $72^{\circ} \mathrm{C}$. Finally, a primer extension at $72^{\circ} \mathrm{C}$ for $7 \mathrm{~min}$ was conducted. PCR products were detected after $1 \%$ agarose gel electrophoresis and purified using the QIAquick gel extraction kit.

DGGE was conducted on the D-Code System (Bio-Rad) using $8 \%(\mathrm{w} / \mathrm{v})$ polyacrylamide gel (acrylamide: bisacrylamide ratio of 29:1) in $1 \times$ TAE buffer (20 mM Tris acetate, $10 \mathrm{mM}$ acetic acid, $0.5 \mathrm{mM}$ EDTA, pH 8.0). PCR products containing approximately equal amounts of DNA of similar sizes were separated on a gel containing an increasing linear gradient of denaturants (urea and formamide) from $40 \%$ at the top of the gel to $60 \%$ at the bottom. Electrophoresis was conducted at $60^{\circ} \mathrm{C}$ by applying $60 \mathrm{~V}$ to the gel for $15.5 \mathrm{hr}$. After electrophoresis, gels were stained with $1 \times$ TAE buffer containing $1 \times$ SYBR Green (Sigma) and then processed using Gel Doc XR system (Bio-Rad).

\section{DGGE profile analysis}

Twenty-seven bands representing dominant taxa in each sample were selected for further analyses. DNAs were eluted, purified, and cloned using pGEM-T Easy Vector, followed by transformation into $E$. coli $\mathrm{DH} 5$ a competent cells. Clones were selected by white colony selection on LB agar containing $\mathrm{X}$-Gal (5-bromo-4-chloro-3-indoly- $\beta$-D-galactopyranoside) (Promega, USA), IPTG (isopropyl- $\beta$-D-thiogalacto-pyranoside) (Promega), and ampicillin (50 mg/ml). Selected colonies (three colonies per band) were reamplified directly using pGTf $\left(5^{\prime}\right.$ - TAC GAC TCA CTA TAG GGC GA $\left.-3^{\prime}\right)$ and pGTr $\left(5^{\prime}\right.$ - ACT CAA GCT ATG CAT CCA ACG $-3^{\prime}$ ) primers (8). PCR conditions were the same as in the amplification of partial $16 \mathrm{~S}$ rRNA genes. Sequencing was performed with an automated DNA sequencer (ABI3700, Applied Biosystems) according to the manufacturer's instructions. Sequence analysis was carried out using the EzTaxon-e database (http://eztaxon-e.ezbiocloud. net/[19]) and PHYDIT.

\section{Cluster analysis}

Cluster analysis of DGGE profiles was performed by using GelCompar II version 4.6 software (Applied Maths). Quantitative information of each OTU derived from pyrosequencing was used to calculate the similarity of the bacterial composition between seasons using UniFrac distance metric [24]. The unweighted pair group method with averages (UPGMA [33]) was used to express the clustering result.

Table 1. Physicochemical properties of seawater samples collected in Gwangyang bay

\begin{tabular}{lccccc}
\hline Season & Tem. $\left({ }^{\circ} \mathrm{C}\right)$ & Salinity $(\%)$ & HB $\left(10^{3} \times \mathrm{CFU} / \mathrm{ml}\right)$ & Chl. a $\left(\mathrm{mg} / \mathrm{m}^{3}\right)$ & $\mathrm{pH}$ \\
\hline Spring (Apr. 2008) & 11.8 & 29.6 & 17.3 & 1.2 & 8.7 \\
Summer (July 2008) & 23.6 & 28.5 & 14.0 & 2.6 & 8.3 \\
Autumn (Oct. 2008) & 18.2 & 30.2 & 38.0 & 6.3 & 8.3 \\
Winter (Feb. 2009) & 4.4 & 31.9 & 4.7 & 8.0 \\
\hline
\end{tabular}

※ Tem., temperature; HB, heterotrophic bacteria; Chl. a, chlorophyll a 


\section{Results}

\section{Environmental factors}

Seasonal variations in environmental parameters are described in Table 1 . Heterotrophic bacterial number and chlorophyll a content were higher in autumn and winter, respectively. The $\mathrm{pH}$ value and salinity ranged from 8.0 to $8.3 \%$ and from 29.6 to $31.9 \%$, respectively.

\section{Bacterial community discovered by ARDRA with} isolates

From the isolates, 80 phylotypes, including 39 singlemember phylotypes, were produced by ARDRA using HadII endonuclease. Distribution patterns of the phylotypes produced from bacterial isolates are listed in Table 2. The com- munity of bacterial isolates was composed of four phyla: Firmicutes (101 strains; 50.5\%), Proteobacteria (66; 33\%), Actinobacteria (22; 11\%), and Bacteroidetes (11; 5.5\%). Firmicutes was dominant in spring and summer, whereas Proteobacteria was in autumn and winter (Table 2). Isolates were affiliated as 46 genera composing 27 families. Members of the genus Bacillus dominated in all seasons, whereas those of the genus Erythrobacter did in autumn and winter.

\section{Bacterial community discovered by pyrosequencing}

A total of 140,987 bacterial sequences longer than $300 \mathrm{bp}$ were obtained by pyrosequencing, and the average length was 439 bp. Taxonomic assignment of each sequence was carried out in an automated manner, and the results were a list of the taxonomic assignment of each amplicon as well

Table 2. Bacterial community of Gwangyang bay seawater discovered by ARDRA with isolates

\begin{tabular}{|c|c|c|c|c|c|c|}
\hline Phylum (Class) & Family & Spring & Summer & Autumn & Winter & Sum \\
\hline Proteobacteria & & 2 & 9 & 27 & 28 & 66 \\
\hline \multirow[t]{8}{*}{ (Alphaproteobacteria) } & & (2) & (5) & (17) & (16) & $(40)$ \\
\hline & "Aurantimonadaceae" & & & 1 & & 1 \\
\hline & Caulobacteraceae & & & 1 & & 1 \\
\hline & Erythrobacteraceae & & 2 & 11 & 10 & 23 \\
\hline & Phyllobacteriaceae & 1 & 1 & & & 2 \\
\hline & Rhodobacteraceae & & 1 & 4 & 4 & 9 \\
\hline & Rhodospirillaceae & & & & 2 & 2 \\
\hline & Sphingomonadaceae & 1 & 1 & & & 2 \\
\hline \multirow{9}{*}{ (Gammaproteobacteria) } & & & (4) & (10) & (12) & (26) \\
\hline & Alcanivoracaceae & & & 1 & 1 & 2 \\
\hline & Alteromonadaceae & & & 5 & 2 & 7 \\
\hline & Chromatiaceae & & 1 & & 1 & 2 \\
\hline & Halomonadaceae & & & & 3 & 3 \\
\hline & Idiomarinaceae & & 1 & & & 1 \\
\hline & Pseudoalteromonadaceae & & 1 & 1 & 2 & 4 \\
\hline & Shewanellaceae & & & 1 & 3 & 4 \\
\hline & Vibrionaceae & & 1 & 2 & & 3 \\
\hline \multirow[t]{6}{*}{ Firmicutes } & & 47 & 32 & 13 & 9 & 101 \\
\hline & Bacillaceae & 44 & 22 & 12 & 9 & 87 \\
\hline & Paenibacillaceae & & 3 & & & 3 \\
\hline & Planococcaceae & 2 & & & & 2 \\
\hline & Staphylococcaceae & 1 & 5 & 1 & & 7 \\
\hline & Unclassified Bacillales & & 2 & & & 2 \\
\hline \multirow[t]{7}{*}{ Actinobacteria } & & 1 & 7 & 6 & 8 & 22 \\
\hline & Brevibacteriaceae & & 1 & & & 1 \\
\hline & Dietziaceae & & 2 & & & 2 \\
\hline & Intrasporangiaceae & & & & 1 & 1 \\
\hline & Microbacteriaceae & & 2 & 2 & 1 & 5 \\
\hline & Micrococcaceae & 1 & 1 & 4 & 6 & 12 \\
\hline & Nocardiaceae & & 1 & & & 1 \\
\hline Bacteroidetes & Flavobacteriaceae & & 2 & 4 & 5 & 11 \\
\hline Sum & & 50 & 50 & 50 & 50 & 200 \\
\hline
\end{tabular}




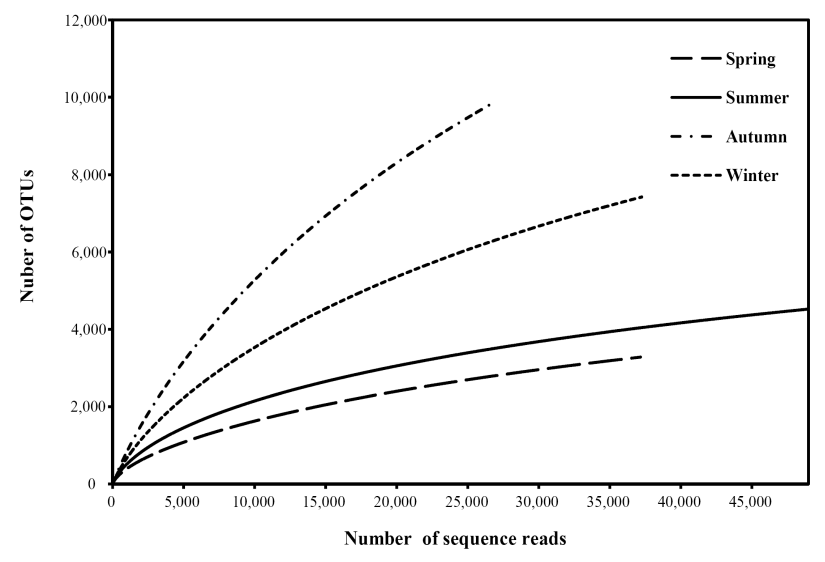

Fig. 1. Rarefaction curves for sequence reads obtained from the pyrosequencing analysis using DNA extracts obtained from Gwangyang bay seawter. Rarefaction curves were calculated from operational taxonomic unit (OTU) analysis of $97 \%$ identical sequence type.

as the number of amplicons in each major taxonomic rank. Fig. 1 shows the rarefaction analysis based on best matches between each tag and sequences in the EzTaxon-e database database [19], along with their frequency of recovery. These rarefaction curves describe unprecedented levels of bacterial complexity for marine samples, yet none has reached the curvilinear or plateau phase. The statistical richness estimates of ACE and Chao1 determined by the DOTUR program are given in Table 3. Shannon-Weaver diversity, ACE, and Chao1 values were higher in autumn, whereas Simpson dominance index was higher in spring. Taxonomic/phylogenetic assignment of bacterial sequences indicated that the sample contained 19 divisions, 21 candidate divisions, and five new divisions. Seasonal variations in the number of divisions were as follows: 24, 24, 39, and 32 in spring, summer, autumn, and winter, respectively. Phylum Proteobacteria was the most abundant (48.85\% of total bacteria), followed by Firmicutes (36.72\%), Bacteroidetes (6.23\%), Planctomycetes $(3.12 \%)$, and Actinobacteria $(1.96 \%)$. The other 38 divisions presented only in minor components (data not shown). In the phylum Proteobacteria, class Alphaproteobacteria
(80.71\% of Proteobacteria) was the most abundant, followed by the class Gammaproteobacteria. A small portion of the reads (1,268 reads) was assigned to 21 candidate divisions for which no cultural representatives are available (data not shown). Candidate division OD1 was the most abundant group $(0.24 \%$ of total bacteria), followed by candidate divisions OP11 (0.22\%), SAR202 (0.12\%), and GN02 (0.11\%).

In spring, phylum Firmicutes dominated $(85.24 \%$ of the total reads) and consisted of 12 genera with the genus Bacillus predominating (81.5\%) (Fig. 2A). In summer, phylum Proteobacteria $(52.18 \%)$ dominated, followed by phyla Firmicutes (39.68\%), Bacteroidetes (2.91\%), and Actinobacteria (2.64\%) (Fig. 2B). Phylum Proteobacteria consisted of 171 genera with the genus Tropicibacter (family Rhodobacteracead) predominating (7,536 reads; $15.41 \%)$. Phylum Firmicutes consisted of nine genera with the genus Bacillus predominating $(35.04 \%)$. In autumn, phylum Proteobacteria (69.85\%) dominated, followed by phyla Bacteroidetes (9.84\%), Planctomycetes (6.94\%), Acidobacteria (2.94\%), Actinobacteria $(2.31 \%)$, and Firmicutes (1.89\%) (Fig. 2C). Phyla Deinococcus- Thermus and Tenericutes appeared exclusively in this season. In winter, phylum Proteobacteria $(77.74 \%)$ dominated, followed by phyla Bacteroidetes $(15.54 \%)$, Actinobacteria $(2.27 \%)$, and Verrucomicrobia $(1.34 \%)$ (Fig. 2D). The family Rhodobacteraceae (class Alphaproteobacteria) predominating (50.71\%). Phyla Fibrobacteres and Spirochaetes appeared exclusively in this season.

Variations between seasons in the SAR11 clade, which is prevalent in seawater DNA (Morris et al., 2002), slightly occurred in spring $(0.22 \%)$ and summer $(0.3 \%)$, whereas they were more abundant in autumn $(1.47 \%)$ and winter $(8.5 \%)$.

\section{Dominant bacterial community discovered by DGGE}

Overall bacterial compositions of DGGE profiles are summarized in Fig. 3 and Table 4. Six families in two phyla (Firmicutes and Proteobacteria) were detected in spring.

Table 3. Summary of pyrosequencing data of DNA extracts from Gwangyang bay seawater

\begin{tabular}{lcccccccc}
\hline Season & Reads & $\begin{array}{c}\text { Average read } \\
\text { length }(\mathrm{bp})\end{array}$ & Coverage & OTUs & ACE & Chao1 & Shannon index & Simpson index \\
\hline Spring & 37,142 & 445 & 57.0 & 3,282 & 7041.4 & 5415.1 & 5.905 \\
Summer & 48,906 & 436 & 79.2 & 4,525 & 6756.9 & 6622.3 & 6.642 & 0.012 \\
Autumn & 25,984 & 443 & 74.7 & 9,873 & 24306.5 & 17734.1 & 8.466 & 0.005 \\
Winter & 28,955 & 433 & 35.6 & 7,423 & 15218.8 & 11701.5 & 7.542 & 0.001 \\
\hline Total & 140,987 & & & & & &
\end{tabular}



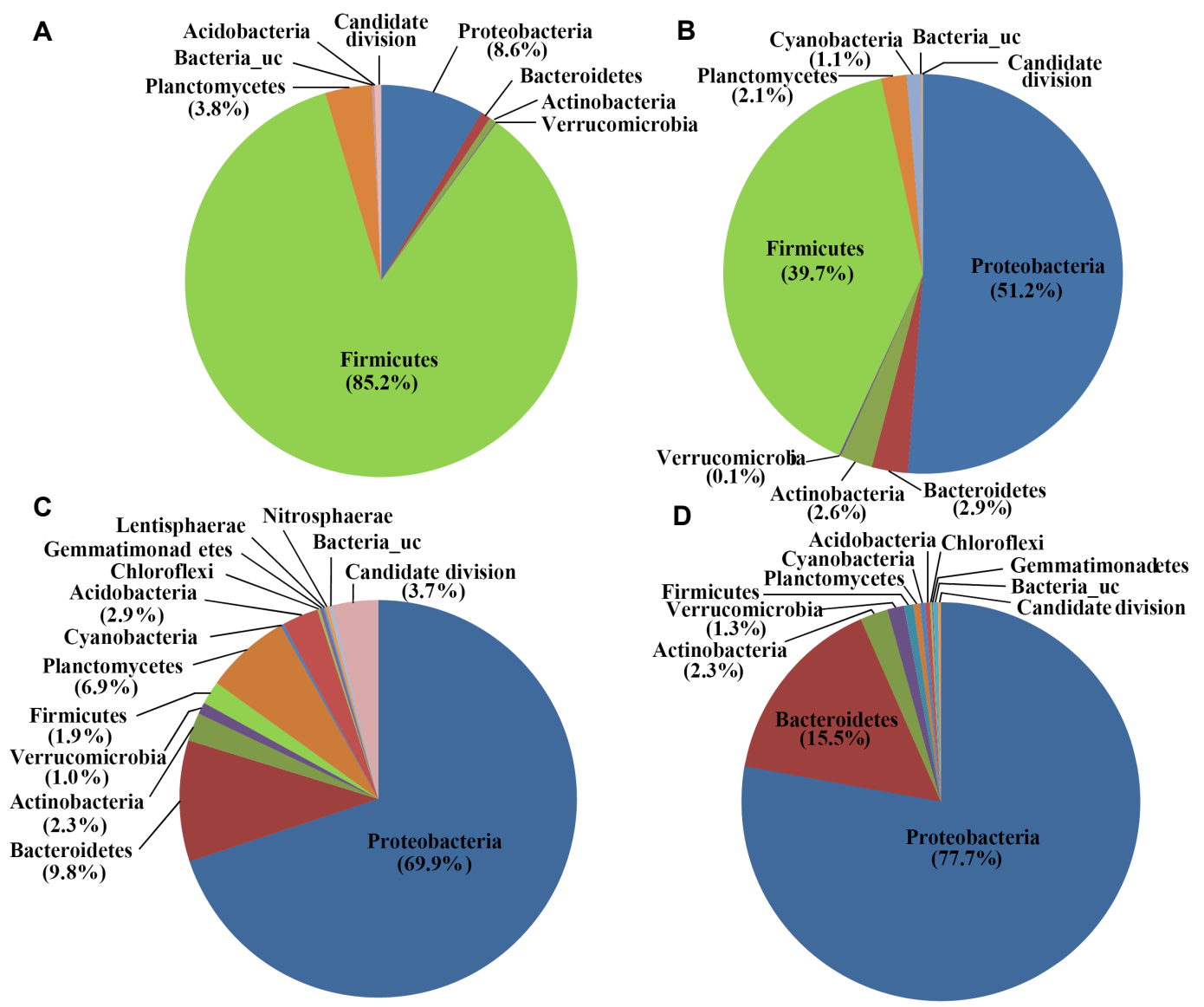

Fig. 2. Relative abundance of bacterial pyrosequences on the phylum level obtained from Gwangyang bay seawater. Percentage of each phylum was calculated and shown if higher than 1\%. (A), spring; (B), summer; (C), autumn; (D), winter.

Clones from intensive bands were affiliated with the genera Bacillus, Sphingobium, Sphingomonas, Acinetobacter, Tateyamaria, and Nevskia. In summer, three phyla (Proteobacteria, Firmicutes, and Actinobacteria) composed of six families were detected. The intensive bands represent the genera Seohaeicola, Tateyamaria, Nautella, Sulfitobacter, Thiohalocapsa, Mesorhizobium, Bacillus, Oceanobacillus, Microlunatus, and Propionibacterium Members of phyla Proteobacteria and Actinobacteria increased in amount, whereas that of Firmicutes decreased. In autumn, the most dominant bacteria were the members of phylum Proteobacteria. Phyla Actinobacteria and Bacteroidetes were detected in only one band each. In winter, four phyla composed of seven families were detected, and the members of families Rhodobacteraceae and Chromatiaceae of phylum Proteobacteria were abundant.

\section{Cluster analysis}

Bacterial composition in spring derived from DGGE was different from that of the other seasons (Fig. 4). This relationship was also confirmed by cluster analysis using the py- rosequencing data, in which the diversity index of spring was lower than that of the other seasons.

\section{Discussion}

Recently, most studies on the bacterial diversity have been carried out based on cultivation-independent $16 \mathrm{~S}$ rRNA gene clones. For sequencing of the 16S rRNA gene, a modified Sanger method or next-generation techniques [12, $20,25]$ are typically used. However, there have been few comprehensive studies using isolation techniques. A previous comprehensive study [25] compared the retrieving capacity of the cultivation-dependent method with that of pyrosequencing, a cultivation-independent method, still having weakness not obtaining pure isolates. Instead, it only used DNA information from viable cells colonized on plates, enriched culture, or grown in microtiter plates. Meanwhile, this study used cultivation-dependent and -independent methods to investigate the bacterial community structure of Gwangyang bay seawater. This study is the first to compre- 
Table 4. Sequence information for the bands obtained from DGGE using DNA extracts from Gwangyang bay seawater

\begin{tabular}{|c|c|c|c|c|c|c|}
\hline Phylum (Class)/Species & Family & Band No. & Spring & Summer & Autumn & Winter \\
\hline \multicolumn{7}{|l|}{$\begin{array}{l}\text { Proteobacteria } \\
\text { (Alphaproteobacteria) }\end{array}$} \\
\hline Albidiferax ferrireducens & Comamonadaceae & 19 & & & + & \\
\hline Mesorhizobium temperatum & Phyllobacteriaceae & 13 & & + & & + \\
\hline Dinoroseobacter shibae & Rhodobacteraceae & 27 & & & & + \\
\hline Nautella italicas & Rhodobacteraceae & 8 & & + & & \\
\hline Seohaeicola saemankumensis & Rhodobacteraceae & 12,26 & & + & + & + \\
\hline Sulfitobacter donghicola & Rhodobacteraceae & 27 & & & & + \\
\hline Sulfitobacter mediterraneus & Rhodobacteraceae & 20 & & + & + & \\
\hline Tateyamaria pelophila & Rhodobacteraceae & 15 & + & + & & \\
\hline Sphingobium aromaticiconvertens & Sphingomonadaceae & 5 & + & & + & \\
\hline Sphingomonas xinjiangensis & Sphingomonadaceae & 2 & + & & & \\
\hline \multicolumn{7}{|l|}{ (Deltaproteobacteria) } \\
\hline Geobacter toluenoxydans & Geobacteraceae & 17 & & & + & \\
\hline \multicolumn{7}{|l|}{ (Gammaproteobacteria) } \\
\hline Thiohalocapsa halophile & Chromatiaceae & 10,24 & & + & + & + \\
\hline Acinetobacter radioresistens & Moraxellaceae & 21 & + & & + & \\
\hline Pseudomonas veronii & Pseudomonadaceae & 23 & & & & + \\
\hline Nevskia ramose & Sinobacteraceae & 1 & + & & & \\
\hline \multicolumn{7}{|l|}{ Firmicutes } \\
\hline Bacillus aryabhattai & Bacillaceae & 11,9 & & + & & \\
\hline Bacillus licheniformis & Bacillaceae & 4,6 & + & & & \\
\hline Bacillus nanhaiensis & Bacillaceae & 3 & + & & & \\
\hline Bacillus thioparans & Bacillaceae & $4,5,6$ & + & & & + \\
\hline Oceanobacillus chironomi & Bacillaceae & 9 & & + & & \\
\hline \multicolumn{7}{|l|}{ Actinobacteria } \\
\hline Microlunatus phosphovorus & Propionibacteriaceae & 14 & & + & + & \\
\hline Propionibacterium acnes & Propionibacteriaceae & 25 & & & & + \\
\hline \multicolumn{7}{|l|}{ Bacteroidetes } \\
\hline Mesonia mobilis & Flavobacteriaceae & 18 & & & + & \\
\hline Polaribacter dokdonensis & Flavobacteriaceae & 22 & & & & + \\
\hline
\end{tabular}

+: Detected sequences in the clone obtained from DGGE band.

hensively study the bacterial diversity of Gwangyang bay seawater.

The bacterial community of Gwangyang bay seawater based on pyrosequencing data was composed of 45 phyla, whereas that of the Yellow Sea contains 53 phyla, including candidate or new divisions [25]. This can be attributed to the different environmental conditions and sampling methods between the two experiments; i.e. two depth samples were used in the latter while four seasonal samples at a single site were used in this study. Bacterial communities of seawater mainly consisted of Proteobacteria (a-subdivision, $\beta$-subdivision, $\gamma$-subdivision), Actinobacteria, and Bacteroidetes $[15,20,23,25]$. In addition to the common predominant members, dominance of Firmicutes $[15,18,23]$ and Cyanobacteria [23] was reported. In this study, dominance of Firmicutes was a special case, especially in spring. This was due to the different environmental conditions, such as water temperature and content of chrolophyll a. In addition, geographical properties might have altered bacterial composition, as our sampling site was located in a bay influenced by the Seumjin river. In addition to common constituents, Planctomycetes was considerably detected in spring, summer, and autumn in amounts of 3.84, 2.05, and 6.96\%, respectively. Abundance of Planctomycetes has been reported in marine sediments of the Eastern Mediterranean Sea $[30,31]$. However, members of phylum Cyanobacteria were found only in small portions (at most 1.07\%) in summer. The presence of only a small number of environmental uncultured bacteria that were distantly related to cultivated ones in this study was also reported in the Yellow Sea [25].

Bacterial communities derived from the cultivation-de- 


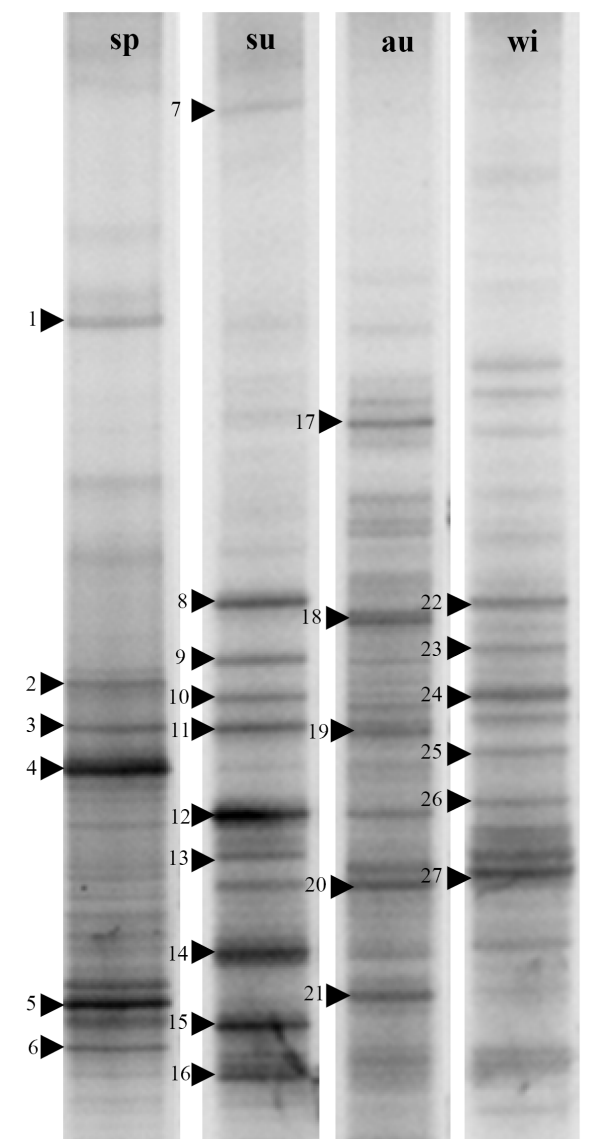

Fig. 3. DGGE profiles of bacterial DNA extracted from Gwangyang bay seawater. Lanes: sp, spring; $\mathrm{su}$, summer; au, autumn; wi, winter.

pendent analysis and DGGE profiles revealed only four phyla, Proteobacteria, Actinobacteria, Bacteroidetes, and Firmicutes. While pyrosequencing data showed the phyla Planctomycetes, Acidobacteria, Cyanobacteria, and Verrucomicrobia exceeded $1 \%$ at least in any one season, the four phyla were not detected in both of the cultivation-dependent and DGGE analyses. Nevertheless, four common dominant phyla were retrieved in the pyrosequencing analysis.

Although only a small number of environmental parameters were obtained, the content of chlorophyll a and heterotrophic bacterial abundance were related to bacterial diversity. More information on environmental factors such as nutrients and metal ions should be obtained and compared with the bacterial community.

ARDRA with cultivated bacterial strains revealed only a small portion of the bacterial community in this study. Moreover, members of phylum Firmicutes were the most predominant. However, this analysis showed the distribution tendency of the bacterial composition; the number of Proteobacteria increased while that of Firmicutes decreased from spring to winter. Estimation of bacterial composition based on the isolation technique had a limitation in terms of the number of isolates. In addition, there were several biases in the cultivation and selection stages; most of the bacteria were uncultivable under single culture medium and incubation conditions, and slow-growing bacteria could be rejected in the selection process $[13,17]$. Despite the limitations of the culture-dependent analysis, several strains were found to be novel species, which were supported by the comparative sequence similarity and phylogenetic analyses. Four species have already been validly published: Marinivirga aestuarii (strain KYW371 [28]), Altererythrobacter namhicola (strain KYW48 [26]), Pseudidiomarina aestuarii (strain KYW314 [29]), and Shewanella marina (strain C4 [27]).

\section{Acknowledgement}

This research was supported by the Basic Science

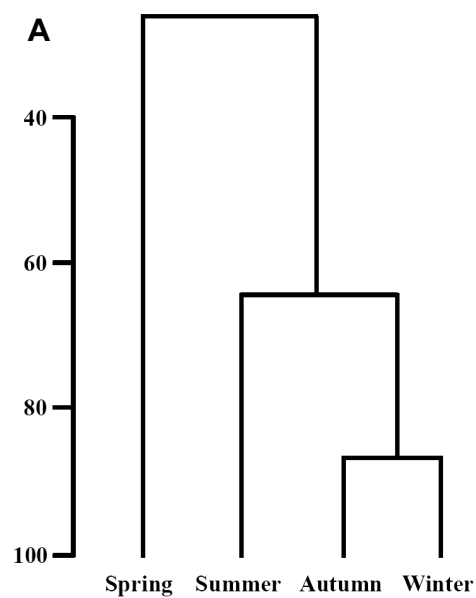

Fig. 4. Relatedness of seasonal bacterial communities of Gwangyang bay seawater. Data are obtained from pyrosequencing (A) and DGGE (B). 
Research Program through the National Research Foundation of Korea funded by the Ministry of Education, Science and Technology (No. 2010-0006861).

\section{References}

1. American Public Health Association. 1989. Standard Methods for the Examination of Water and Wastewater, 17th ed., Washington, D. C., USA.

2. Baek, S. H., Kim, D. S., Hyun, B. G., Choi, H. W. and Kim, Y. O. 2011. Characteristics of horizontal community distribution and nutrient limitation on growth rate of phytoplankton during a winter in Gwangyang bay, Korea. Ocean Polar Res 33, 99-111.

3. Baik, K. S. 2005. Prokaryotic diversity of Woopo wetland estimated by phylogenetic analysis. Ph. D. Thesis, Sunchon National University. Korea.

4. Chao, A. 1984. Nonparametric-estimation of the number of classes in a population. Scand J Stat 11, 265-270.

5. Chao, A. and Lee, S. M. 1992. Estimating the number of classes via sample coverage. J Am Stat Assoc 87, 210-217.

6. Choi, C. G. and Huh, S. H. 2008. Composition of marine algal community at the intertidal zone in Gwangyang bay, South Sea, Korea. Korran J Fisher Aqua Sci 41, 201-207.

7. Chun, J. and Goodfellow, M. 1995. A phylogenetic analysis of the genus Nocardia with 16S rRNA gene sequences. Int J Syst Bacteriol 45, 240-245.

8. Chun, J., Huq, A. and Colwell, R. R. 1999. Analysis of 16S-23S rRNA intergenic spacer regions of Vibrio cholerae and Vibrio mimicus. Appl Environ Microbiol 65, 2202-2208.

9. Chun, J., Kim, K. Y., Lee, J.-H. and Choi, Y. 2010. The analysis of oral microbial communities of wild-type and Toll-like receptor 2-deficient mice using a 454 GS FLX Titanium Pyrosequencer. BMC Microbiol 10, 101.

10. Cole, J. R., Wang, Q., Cardenas, E., Fish, J., Chai, B., Farris, R. J., Kulam-Syed-Mohideen, A. S., McGarrell, D. M., Marsh, T., Garrity, G. M. and Tiedje, J. M. 2009. The ribosomal database project: improved alignments and new tools for rRNA analysis. Nucleic Acids Res 37, D141-D145.

11. Droege, M. and Hil, B. 2008. The Genome Sequencer FLX System-longer reads, more applications, straight forward bioinformatics and more complete data sets. J Biotechnol 31, 3-10.

12. Galand, P. E., Bourrain, M., De Maistre, E., Catala, P., Desdevises, Y., Elifantz, H., Kirchman, D. L. and Lebaron, P. 2012. Phylogenetic and functional diversity of bacteria and archaea in a unique stratified lagoon, the clipperton atoll (N Pacific). FEMS Microbiol Ecol 82, 616-628.

13. Ghosh, A., Maity, B., Chakrabarti, K. and Chattopadhyay, D. 2007. Bacterial diversity of East Calcutta wet land area: possible identification of potential bacterial population for different biotechnological uses. Microb Ecol 54, 452 - 459.

14. Heck, K. L., Van Belle, G. and Simberloff, D. 1975. Explicit calculation of the rarefaction diversity measurement and the determination of sufficient sample size. Ecol 56, 1459-1461.
15. Henriques, I. S., Almeida, A., Cunha, A. and Correia, A. 2004. Molecular sequence analysis of prokaryotic diversity in the middle and outer sections of the Portuguese estuary Ria de Aveiro. FEMS Microbiol Ecol 49, 269-279.

16. Hurlbert, S. H. 1971. The nonconcept of species diversity: a critique and alternative parameters. Ecol 52, 577-586.

17. Joshi, A. A., Kanekar, P. P., Kelkar, A. S., Shouche, Y. S., Vani, A. A., Borgave, S. B. and Sarnaik, S. S. 2008. Cultivable bacterial diversity of alkaline Lonar lake, India. Microb Ecol 55, 163-172.

18. Kim, B.-S., Kim, B. K., Lee, J.-H., Kim, M., Lim, Y. W. and Chun, J. 2008. Rapid phylogenetic dissection of prokaryotic structure in tidal flat using pyrosequencing. J Microbiol 46, 357-363.

19. Kim, O. S., Cho, Y. J., Lee, K., Yoon, S. H., Kim, M., Na, H., Park, S. C., Jeon, Y. S., Lee, J. H., Yi, H., Won, S. and Chun, J. 2012. Introducing EzTaxon-e: a prokaryotic 16S rRNA gene sequence database with phylotypes that represent uncultured species. Int J Syst Evol Microbiol 62, 716-721.

20. Kirchman, D. L., Cottrell, M. T. and Lovejoy, C. 2010. The structure of bacterial communities in the western Arctic Ocean as revealed by pyrosequencing of 16S rRNA genes. Environ Microbiol 12, 1132-1143.

21. Lane, D. J. 1991. 16S/23S rRNA sequencing, pp. 115 - 175. In E. Stackebrandt \& M. Goodfellow (ed.), Nucleic acid techniques in bacterial systematics, Wiley, Chichester, U.K.

22. Lee, Y. S., Kang, C.-K., Choi, Y.-K. and Leem S. Y. 2007. Origin and spatial distribution of organic matter at Gwangyang bay in the fall. Ocean Science J 12, 1-8.

23. Ling, J., Dong, J. D., Wang, Y. S., Zhang, Y. Y., Deng, C., Lin, L., Wu, M. L. and Sun, F. L. 2012. Spatial variation of bacterial community structure of the Northern South China Sea in relation to water chemistry. Ecotoxicol 21, 1669-1679.

24. Lozupone, C. and Knight, R. 2005. UniFrac: a new phylogenetic method for comparing microbial communities. Appl Environ Microbiol 71, 8228-8235.

25. Na, H., Kim, O.-S., Yoon, S.-H., Kim, Y. and Chun, J. 2011. Comparative approach to capture bacterial diversity of coastal waters. J Microbiol 49, 729-740.

26. Park, S. C., Baik, K. S., Choe, H. N., Lim, C. H., Kim, H. J., Ka, J. O. and Seong, C. N. 2011. Altererythrobacter namhicola sp. nov., and Altererythrobacter aestuarii sp. nov., isolated from seawater. Int J Syst Evol Microbiol 61, 709-715.

27. Park, S. C, Baik, K. S., Kim, M. S., Kim, D. and Seong, C. N. 2009. Shewanella marina sp. nov., isolated from seawater. Int J Syst Evol Microbiol 59, 1888-1894.

28. Park, S. C., Choe, H. N., Hwang, Y. M., Baik, K. S., Kim, S. N., Lee, Y. S., Jung, J. S. and Seong, C. N. 2013. Marinivirga aestuarii gen. nov., sp. nov., a novel member of the family Flavobacteriaceae, isolated from marine environment, and emended descriptions of the genera Hyunsoonleella, Jejuia and Pontirhabdus and Hyunsoonleella jejuensis, Jejuia pallidilutea and Pontirhabdus pectinivorans. Int J Syst Evol Microbiol 63, 1524-1531.

29. Park, S. C., Lim, C. H., Baik, K. S., Lee, K. H., Lee, J. S. 
and Seong, C. N. 2010. Pseudidiomarina aestuarii sp. nov., a marine bacterium isolated from shallow coastal seawater. Int J Syst Evol Microbiol 60, 2071-2075.

30. Polymenakou, P. N., Bertilsson, S., Tselepides, A. and Stephanou, E. G. 2005. Bacterial community composition in different sediments from the Eastern Mediterranean Sea: a comparison of four $16 \mathrm{~S}$ ribosomal DNA clone libraries. Microb Ecol 50, 447-462.

31. Polymenakou, P. N., Lampadariou, N., Mandalakis, M. and Tselepides, A. 2009. Phylogenetic diversity of sediment bacteria from the southern Cretan margin, Eastern Mediterranean Sea. Syst Appl Microbiol 32, 17-26.

32. Schloss, P. D. and Handelsman, J. 2005. Introducing DOTUR, a computer program for defining operational taxo- nomic units and estimating species richness. Appl Environ Microbiol 71, 1501-1506.

33. Sokal, D. M. and Michener, C. D. 1958. A statistical method for evaluating systematic relationship. Univ. Kansas. Sci Bull 38, 1409-1438.

34. Somerville, C. C., Knight, I. T., Straube, W. L. and Colwell, R. R. 1989. Simple, rapid method for direct isolation of nucleic acids from aquatic environments. Appl Environ Microbiol 55, 548-554.

35. Wright, E. S., Yilmaz, L. S. and Noguera, D. R. 2012. DECIPHER, a search-based approach to chimera identification for $16 \mathrm{~S}$ rRNA sequences. Appl Environ Microbiol 78, 717-725.

\title{
초록 : 광양만 해수의 세균 군집의 계절적 변화
}

\author{
박성찬 $^{1} \cdot$ 이지희 ${ }^{2} \cdot$ 강주원 $^{2} \cdot$ 백근식 $^{3} \cdot$ 성치남 $^{2 *}$ \\ ( ${ }^{1}$ 우진 $\mathrm{B \& G}{ }^{2}$ 순천대학교 생물학과, ${ }^{3}$ 한국기초과학지원연구원)
}

광양만 해수의 세균 군집의 계절적 변화를 배양법과 비배양법을 사용하여 분석하였다. 200개의 분리 균주에 대해 Amplified rDNA restriction 방법을 적용한 경우 분리 균은 Firmicutes, Proteobacteria, Actinobacteria, Bacteroidetes의 4 개의 문에 속함을 확인하였다. 비 배양방법으로는 해수로부터 직접 추출한 DNA를 사용하여 pyrosequencing 과 변성 농도구배 전기영동(DGGE)을 실시하였다. Pyrosequencing에 의한 $16 \mathrm{~S}$ rRNA 유전자의 염 기서열 분석 결과 세균 군집은 춘계와 하계에 각각 24 개, 추계에 39 개 그리고 동계에 32 개의 문으로 구성되었다. 다양도 지수는 추계에 높았으며 춘계에는 우점도 지수가 높았다. Firmicutes 문의 세균이 춘계에 예외적으로 많은 비율을 차지하였으며 나머지 계절에는 Proteobacteria 문의 세균이 우점하였다. 차 우점 분류군은 춘계에는 Proteobacteria 문의 세균인 반면 하계에는 Firmicutes 문, 추계와 동계에는 Bacteroidetes 문의 세균이 차지하였다. 과 수준에서의 우점 분류군은 Bacilliaceaeㅏㅏ 춘계에, Rhodobacteraceae와 Bacilliaceaeㅏㅏ 하계에, Rhodobacteracea라 동 계에 나타났으나 추계에는 우점 분류군이 없었다. DGGE 에서 확인된 27 개의 DNA 절편을 추출하여 계통분석을 실시한 결과 춘계에는 Firmicutes 문에 이어 Proteobacteria 문이 우점하였으며 다른 계절에는 Proteobacteria 문이 우점하였다. 두 가지의 비배양법에 의한 군집 분석 결과 문 수준에서의 세균 군집의 계절적 변화는 유사한 경향이 나타났다. 